\title{
赤血球変形能に対する低出力 $\mathrm{He}$ e - N e レーザーの効果
}

\section{飯島 一彦、下山 直人、下山 恵美、野村 明、杉森邦夫、水口 公信}

\section{千葉大学医学部麻酔科}

Effects of He-Ne Low-powered Laser on Red Cell Deformability

Kazuhiko Iijima, Naohito Shimoyama, Megumi Shimoyama, Akira Nomura, Kunio Sugimori, Tadanobu Mizuguchi

Department of Anesthesiology, Chiba University School of Medicine ABSTRACT

This study was designed to investigate the effect of $\mathrm{He}-\mathrm{Ne}$ laser $(\lambda=$ $632.8 \mathrm{~nm}, 8.5 \mathrm{~mW}$; Senkou Med.Mgf.Co., Tokyo) irradiation on human red cell deformability.

Blood samples were obtained from hematologically normal adult donors by veni-puncture. Red cells were washed and adjusted to $30 \% \mathrm{Ht}$ with $0.9 \% \mathrm{NaCl}$ solution $(\mathrm{pH} \mathrm{7.00)}$. Blood sample was divided into three groups. Each group sample was separated into seven 3 ml-working aliquots. The aliquots in Group 1 were irradiated for 0 (control), 1, 3, 5, 10, 15 and 30 minutes within 2 hours after sampling. The aliquots in Grouup 2 and Grouup 3 were storaged $5{ }^{\circ} \mathrm{C}$ for 24 and 36 hours, respectively, and received the irradiations after 12 hours (in both Groups), 24 hours (in Group 2) and 36 hours (in Group 3) from the sampling. Red cell deformability was measured by the Nuclepore $\mathbb{B}$ fliter filtration and presented as the filtration rate.

The deformability was unchanged in Group 1 (fresh cell group) from the control value, but improved significantly in Group 2 and Group 3 (damaged cell groups) after the irradiation.

These results suggest that the irradiations of the laser improve the function of cytoskeltal proteins in damaged human red cells.

はじめに

低出カレーザーは、難治性皮膚潰瘍、関節リ ウマチ、筋腱膜性疼痛、帶状疮疹後神経痛など 治療に用いられている。われわれは、帶状疮疹 後神経痛に対するレーザーの繰り返し照射の有

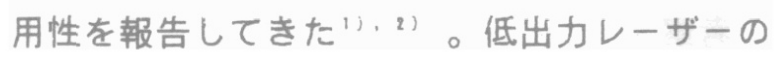

鎮痛効果の発生機序に関して、レーザー照射の 痛覚神経下行性抑制系の賦活")、交感神経系シ ナプスの伝達抑制 “)、赤血球の膜安定化効果 31 などを報告してきた。Karu()によれば、低酸素 下とか還元剂を用いた脱酸素の条件下では、各 種の酵素蛋白が活性化されてエネルギー代謝を 
レーザー照射が改善するという。われわれは、 赤血球の裏打ち構造蛋白にもレーザーが影響を 及ぼすのではなかろうかと赤血球変形能をマイ クロフィルター法によるフィルター通過速度よ り調べてみた。

実験方法 :

健康成人よりヘパリン化血約 $60 \mathrm{~m} \mid$ を採取し、 pH 7.0に調整した生理食塩水にて2 回遠沈洗浄 した後、 $\mathrm{H} \mathrm{t} 30 \%$ 赤血球浮遊液とした。この血球 浮遊液を 3 群に分け、おのおのを更に $3 \mathrm{~m}$ Iず つ 7 本の試験管に細分化した。第 1 群の 7 本は 直ちに $\mathrm{He}-\mathrm{Ne}$ レーザー（出力 $8.5 \mathrm{~mW}$, 波長 $632.8 \mathrm{n}$ $\mathrm{m}$, 泉工医科工業製）をおのおの $0,1,3,5,10,15$ , 30 分づつ照射後、フィルター試験を行った。

第 2 群は $0{ }^{\circ} \mathrm{C} 12$ 時間保存後、第 1 群之同様の レーザー照射をし、更に $0{ }^{\circ} \mathrm{C} 12$ 時間保存後、再 度レーザー照射してフィルター試験を行った。

第 3 群は $0{ }^{\circ} \mathrm{C} 12$ 時間保存後、同様のレーザー 照射をし、更に0 ${ }^{\circ} \mathrm{C} 24$ 時間保存後、レーザーを 照射し、フィルター試験を行った。

マイクロフィルター法は、Ried") の変法によ り、Nuclepore 社製へモフィルター（小孔直径 5 ミクロン、小孔密度 $4 \times 10^{5}$ 個 $/ \mathrm{cm}^{2}$ 、膜 直径 $13 \mathrm{~mm}$ 、膜厚さ10ミクロン) およびホルダー を用い、 $\mathrm{Ht} 30 \%$ 赤血球浮遊液 $0.5 \mathrm{~m} /$ が $-10 \mathrm{~cm}$ 水 柱圧下でのフィルター通過時間より $\mu \mathrm{I} / \mathrm{s}(\mathrm{Fi})$ ter Filtration Rate: FFR) とした。

結果 :

新鮮赤血球の第 1 群、24時間およひ36時間保 存の第 2 群、第 3 群の非照射の対照值は、図 1

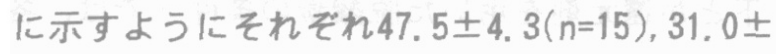
3. $1(n=15), 16.0 \pm 2.0(n=15) \mu / / s$ であり、保
存時間に一致して F F R が隇少し、赤血球変形 能の低下を認めた。

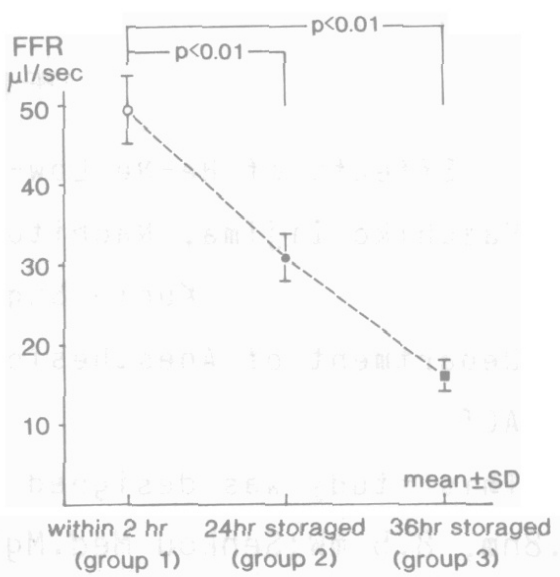

図 1、レーザー非照射の新鮮血（第 1 群）、24 時間および36時間保存（第 2 群、第 3 群）赤血 球のフィルター透過速度FFR

第 1 群、第 2 群、第 3 群におけるレーザー照 射後のFFR の変化は、図 2 に示した。新鮮な血 球においてはレーザー照射は赤血球変形能に影 響を及ぼさないが、24時間保存の第 2 群では、 照射 1 分から10分にかけて変形能の改善を認め 、36時間保存の第 3 群は照射 1 分から15分まで 有意な変形能の改善を認めた。

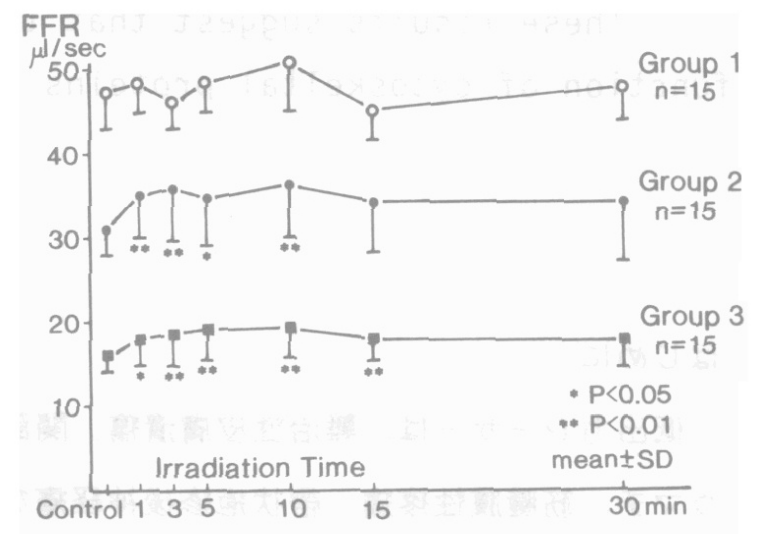

図 2.レーザー照射後の FFRの変化 
われわれは低張性溶血にける低出力 $\mathrm{He}-\mathrm{Ne} レ$ ーザーの赤血球膜安定化効果は、新鮮血球では 出現せず、 1 昼夜 $5{ }^{\circ} \mathrm{C}$ 冷所保存し血球に侵襲 を加えた状態において出現することを証明しら) 、低出カレーザーのホメオスタシス効果を示唆 してきた。しかしながら膜の裏打ち蛋白である スペクトリンなどの機能への影響までは調べる ことができなかった。この度、Riedら"のフィ ルター法にHt $30 \%$ 赤血球を用い、レーザーによ る变形能への効果を調べてみた。

結果は、低張性溶血と同様に新鮮血ではレー ザー照射の効果は出現しないものの侵襲を加え た状態では、低出カレーザーが変形能の改善つ まり膜蛋白機能にもホメオスタシスを保つべく 作用していることが示唆された。

文献

1) Iijima K, et al.; Effect of repeated irradiation of low-power $\mathrm{He}-\mathrm{Ne}$ laser in pain relief from postherpetic neuralgia. $\mathrm{Cl}$ in $\mathrm{J}$ of Pain 5:271-274, 1989

2) Iijima K, et al.; Evaluation of analgesic effect of low-power He-Ne laser on postherpetic neuralgia using VAS and modified McGill pain questionnaire. $J$ of $\mathrm{Cl}$ in Laser Med \& Surg 9:121-126, 1991

3）下山直人ほか：ラット後肢へのホルマリン 注入により脊剈道後角細胞に惹起される活動に 対する低出カレーザー照射の効果。日本レー ザー医誌10:89-92, 1989

4）下山恵美ほか：ラットの上䅡神経節に対す る低出カレーザー照射の効果。麻醉 $40: S 480$, 1991
5) lijima K, et al.; The effect of low power He-Ne laser on hypotonic hemolys is of human erythrocytes. J of Bloodless Medicine and Surgery (JBMS). 8:17-19, 1990

6) karu, $\mathrm{Tl}$ : Photobiological fundamentals of low-power laser therapy. IEEE $\mathrm{J}$ of Quantum electronics. QE-23(10)1703-1717, 1987

7) Reid HL, et al., : A simple method for measuring erythrocyte deformability.

$\mathrm{J}$ Cl in. Path. 29:855-861. 1976 